Original article

\title{
EFFECTIVENESS OF STRUCTURED TEACHING PROGRAM ME ON KNOWLEDGE OF POLYCYSTIC OVARIAN SYNDROME AMONG ADOLESCENT GIRLS
}

\author{
Sowmya M.A $A^{1} \&$ Philomena Fernandes ${ }^{2}$ \\ ${ }^{1}$ II year M.Sc. (N) student, ${ }^{2}$ Associate Professor \& HOD, Department of OBG Nursing, \\ Nitte Usha Institute of Nursing Sciences, Nitte University, M angalore - 575 018, India. \\ Correspondence: \\ Philomena Fernandes \\ Associate Professor \& HOD, Department of OBG Nursing, Nitte Usha Institute of Nursing Sciences, \\ Nitte University, Mangalore - 575 018, India \\ M obile: +9194492 07845. E-mail : philferns7@gmail.com
}

\begin{abstract}
:
The study was conducted to assess the effectiveness of structured teaching programme on knowledge of polycystic ovarian syndrome among adolescent girls. The study design adopted was pre experimental one group pre-test post- test design. The demographic Proforma were collected from the adolescent girls by using structured knowledge questionnaire. Data obtained in these areas were analysed using descriptive and inferential statistics. A significant difference between pre test and post test knowledge was found $\left(\mathrm{t}_{79} 2.0\right.$ $\mathrm{p} \varangle$.05).The study findings showed that the structured teaching programme was effective in improving knowledge of adolescent girls regarding polycystic ovarian syndrome. There was no significant association between the level of knowledge and demographic variables except the group in which they study (Science, Arts, Commerce)
\end{abstract}

Keywords: knowledge, structured teaching programme, PCOS

\section{Introduction:}

Adolescence is a period of transition between childhood and adulthood, a time of profound biological, intellectual, psychological, and economic changes. During this period individual reaches physical and sexual maturity, develop more sophisticated reasoning abilities. The changes of adolescence have important implications for understanding the kinds of health risks to which young people are exposed, the health enhancing and risk taking behaviours in which they engage, and the major opportunities for health promotion among this population ${ }^{1 .}$ This transition from childhood to adolescence is a journey with full of surprises, both for the parents and

\begin{tabular}{|c|}
\hline Access this article online \\
\hline Quick Response Code \\
\hline
\end{tabular}
the children. There are many adolescent problems that stem up while passing through this phase. This is the time when they need guidance and care ${ }^{2}$. Gynaecological diseases are fairly common but most of the women ignore the symptoms or they are unaware, till the time the problem really worsens. One of them, now a day's faced by girls, is polycystic ovarian syndrome. ${ }^{3}$

Polycystic ovarian syndrome (PCOS) was formerly called Stein-Levinthal Syndrome. In 1935 Dr. Stein and Levinthal described a syndrome in which women suffered irregular and usually rare periods, hirsutism (hair growth), and varying degrees of infertility ${ }^{4}$. PCOS is a common health problem among teenage girls and young women. It affects $5 \%$ to $10 \%$ of women in their reproductive years. ${ }^{5}$

In girls with PCOS, the ovaries produce higher than normal amounts of androgens, and this can interfere with egg development and release. Clinical symptoms of PCOS include: menstrual irregularities, inability to get pregnant due to lack of ovulation, increased hair growth in a male distribution pattern (e.g., on face and chest), acne and obesity ${ }^{6}$.

Although there is no cure for PCOS, there are several ways 
that the condition can be treated and managed. If a girl is overweight or obese, Weight loss can be very effective in lessening many of the health conditions associated with PCOS, such as high blood pressure and diabetes. Sometimes weight loss alone can restore hormone levels to normal, causing many of the symptoms to disappear or become less severe. Healthy food habits and exercise is a great way to help combat the weight gain Talking with other teens and women with PCOS is a great way to share information about treatment and get support?

Lack of knowledge and the negative lifestyle attitude towards polycystic ovarian disease among college girls and not taking any measures to improve their lifestyle pattern is felt by the investigator that these college girls can be helped by assessing their knowledge and with a view to change lifestyle by providing necessary information, so as to help them to get aware about the polycystic ovarian syndrome.

\section{Review of Literature :}

An experimental study was conducted to find out the Effectiveness of (PTP) on PCOS for adolescent girls in a selected pre-university college at M angalore. 50 samples were selected by using simple random technique. The mean pretest knowledge score was $57 \%$ and after conducting structurred teaching programme the score (Post test) was $87 \%$. A significant difference between pretest and post-test knowledge was found. This indicates that structured teaching programme is effective in improving the knowledge of adolescent girls on $\mathrm{PCOS}^{8}$.

\section{Materialsand Methods:}

The research approach used in this study was evaluative approach. Research design used in this study was pre experimental- one group pre test post test design. Population comprised of 80 adolescent girls (16-19yrs) in a selected college at Mangalore. 80 sample were selected using simple random sampling technique.

Structured knowledge questionnaire was administered to collect the data from adolescent girls. The questionnaire consists of 30 items related to polycystic ovarian syndrome.
Apart from the questionnaire demographic proforma was also administered to the subjects.

Pre-test was administered to the participants using structured knowledge questionnaire. After pre test researcher conducted structured teaching programme on polycystic ovarian syndrome. After 7 days of intervention the investigator administered the post test to assess the level of knowledge of adolescent girls using the same structured knowledge questionnaire. The data collected were analysed using frequency percentage, paired t- test and Fishers exact test.

\section{Results:}

The findings are discussed under the following headings.

\section{SECTION 1 : DESCRIPTION OF SAM PLE CHARACTERISTICS}

Table1 : Distribution of adolescent girls according to the mographic characteristics. $n=80$

\begin{tabular}{|l|c|c|}
\hline SAM PLE CHARACTERISTICS & FREQUENCY & PERCENTAGE \\
\hline Age in years & 32 & 40.0 \\
| 16yr & 43 & 53.8 \\
| 17 & 5 & 6.2 \\
| 18 & 0 & 0 \\
| 19 & 42 & 52.5 \\
\hline Religion & 17 & 21.2 \\
| Hindu & 21 & 62.2 \\
| M uslim & & \\
| Christian & 30 & 37.5 \\
\hline Group & 30 & 37.5 \\
| Arts & 20 & 25 \\
| Science & & \\
| Commerce & 1 & 1.2 \\
\hline Education status of parents & 32 & 40.0 \\
a) Education status of the father & & 38.5 \\
| No formal education & 31 & 12.5 \\
| Primary & 11 & 7.5 \\
| Secondary & 6 & \\
| Pre - university & & \\
| Graduation and above & 6.5 \\
b) Education status of themother & & 22.5 \\
| No formal education & 2 & 47.5 \\
| Primary & 18 & 17.5 \\
| Secondary & 38 & 10.5 \\
| Pre - university & 14 & \\
| Graduation and above & 8 & \\
\hline
\end{tabular}




\begin{tabular}{|c|c|c|}
\hline SAM PLE CHARACTERISTICS & FREQUENCY & PERCENTAGE \\
\hline \multicolumn{3}{|c|}{ a) Occupation of the father } \\
\hline I Daily wages & 35 & 43.8 \\
\hline I Employed & 29 & 36.2 \\
\hline I Self employed & 15 & 18.8 \\
\hline I Unemployed & 1 & 1.2 \\
\hline \multicolumn{3}{|l|}{ b) Occupation of the mother } \\
\hline I Daily wages & 7 & 8.8 \\
\hline I Employed & 18 & 22.5 \\
\hline I Self employed & 1 & 1.2 \\
\hline I Unemployed & 54 & 67.5 \\
\hline \multicolumn{3}{|l|}{ Monthly income of the family } \\
\hline $1<3000$ & 7 & 8.8 \\
\hline I 3000-5000 & 27 & 33.8 \\
\hline । 5000-8000 & 22 & 27.5 \\
\hline । 8000-10000 & 16 & 20.0 \\
\hline | $>10000$ & 8 & 10.0 \\
\hline \multicolumn{3}{|l|}{ Type of family } \\
\hline I nuclear & 62 & 77.5 \\
\hline I joint & 14 & 17.5 \\
\hline I extended & 4 & 5.0 \\
\hline \multicolumn{3}{|l|}{ Previous information about PCOS } \\
\hline I health personnel & 0 & 0 \\
\hline I friends, parents, teachers & 0 & 0 \\
\hline I mass media & 0 & 0 \\
\hline I no information & 80 & 100.0 \\
\hline
\end{tabular}

\section{Section 2: Knowledge of adolescent girls on PCOS}

Table2: Distribution of pre-test and post test knowledge scores of the adolescent girlson PCOS

$\mathrm{n}=80$

\begin{tabular}{|l|c|c|c|c|}
\hline $\begin{array}{l}\text { Level of } \\
\text { knowledge }\end{array}$ & \multicolumn{2}{|c|}{$\begin{array}{c}\text { Pretest knowledge } \\
\text { score }\end{array}$} & $\begin{array}{c}\text { Post-test knowledge } \\
\text { score }\end{array}$ \\
\hline & $\begin{array}{c}\text { FREQUENCY } \\
\text { (f) }\end{array}$ & $\begin{array}{c}\text { PERCENTAGE } \\
\text { (\%) }\end{array}$ & $\begin{array}{c}\text { FREQUENCY } \\
\text { (f) }\end{array}$ & $\begin{array}{c}\text { PERCENTAGE } \\
\text { (\%) }\end{array}$ \\
\hline Poor & 56 & 70.0 & - & - \\
\hline Average & 23 & 28.8 & 3 & 3.8 \\
\hline Good & 1 & 1.2 & 24 & 30.0 \\
\hline Very good & - & - & 53 & 66.2 \\
\hline
\end{tabular}

Table 3: M ean median and standard deviation of pre-test and post test knowledge scores

$n=80$

\begin{tabular}{|l|c|c|c|c|c|c|c|}
\hline $\begin{array}{l}\text { Knowledge } \\
\text { scores }\end{array}$ & $\begin{array}{c}\text { Max } \\
\text { possible } \\
\text { scores }\end{array}$ & $\begin{array}{c}\text { Min } \\
\text { score } \\
\text { obtained }\end{array}$ & $\begin{array}{c}\text { Max } \\
\text { score } \\
\text { obtained }\end{array}$ & $\begin{array}{c}\text { Mean } \\
\text { Mean } \\
\%\end{array}$ & Median & SD \\
\hline $\begin{array}{l}\text { Pre-test } \\
\text { knowledge } \\
\text { score }\end{array}$ & 30 & 4 & 18 & $\begin{array}{c}1.31 \\
25\end{array}$ & $\begin{array}{c}4.3 \\
75\end{array}$ & 1.00 & 0.49 \\
\hline $\begin{array}{l}\text { Post-test } \\
\text { knowledge } \\
\text { score }\end{array}$ & 30 & 17 & 30 & 3.6 & 12. & 4.00 & 0.55 \\
& & & & 250 & 083 & & 972 \\
\hline
\end{tabular}

Table 4: Area wise pretest - post test knowledge scores of adolescent girls

\begin{tabular}{|c|c|c|c|c|c|}
\hline \multirow[t]{2}{*}{ Areas } & \multirow[t]{2}{*}{$\begin{array}{c}\text { Maximum } \\
\text { possible } \\
\text { score }\end{array}$} & \multicolumn{2}{|c|}{$\begin{array}{c}\text { Pre test } \\
\text { knowledge } \\
\text { score }\end{array}$} & \multicolumn{2}{|c|}{$\begin{array}{c}\text { Post test } \\
\text { knowledge } \\
\text { score }\end{array}$} \\
\hline & & $\begin{array}{c}\text { mean } \\
+S D\end{array}$ & $\begin{array}{c}\text { mean } \\
\%\end{array}$ & $\begin{array}{c}\text { mean } \\
+S D\end{array}$ & $\begin{array}{c}\text { mean } \\
\%\end{array}$ \\
\hline $\begin{array}{l}\text { Anatomy and } \\
\text { physiology }\end{array}$ & 6 & $\begin{array}{l}2.5+ \\
1.36\end{array}$ & 8.33 & $\begin{array}{c}5.11+ \\
0.94\end{array}$ & 17.03 \\
\hline M eaning \&incidence & 7 & $\begin{array}{c}2.56+ \\
1.29\end{array}$ & 8.53 & $\begin{array}{l}5.65+ \\
1.09\end{array}$ & 18.83 \\
\hline Cause and risk facto & 2 & $\begin{array}{l}0.6+ \\
0.58\end{array}$ & 2 & $\begin{array}{c}1.71+ \\
0.45\end{array}$ & 5.7 \\
\hline $\begin{array}{l}\text { Signs symptoms, } \\
\text { complication }\end{array}$ & 5 & $\begin{array}{c}1.77+ \\
1.07\end{array}$ & 5.9 & $\begin{array}{c}4.08+ \\
0.85\end{array}$ & 13.6 \\
\hline $\begin{array}{l}\text { Prevention \& } \\
\text { management }\end{array}$ & 6 & $\begin{array}{c}2.85+ \\
1.32\end{array}$ & 9.5 & $\begin{array}{l}8.2+ \\
1.31\end{array}$ & 27.33 \\
\hline Total & 30 & & 34.26 & & 82.49 \\
\hline
\end{tabular}

Section III: Evaluation of the Structured Teaching Programme on PCOSin terms of gain in post test knowledge scores

In order to find significant difference between mean pre-test knowledge scores paired " $\mathrm{t}$ " test was used. To test the significance, following hypothesis was stated.

$\mathrm{H}_{1}$; There will be significant difference between the pretest and post level of knowledge about PCOSamong adolescent girls

Table 5: mean, standard deviation, (SD) paired " $\mathrm{t}$ " test between pre-test and post-test knowledge scores of adolescent girls

\begin{tabular}{|l|c|c|c|c|}
\hline $\begin{array}{l}\text { Knowledge } \\
\text { scores }\end{array}$ & Mean & $\begin{array}{c}\text { Standard } \\
\text { deviation }\end{array}$ & "t"value & p value \\
\cline { 1 - 4 } pre-test & 1.3125 & 0.49283 & 65.205 & \multirow{2}{*}{$.001 \mathrm{~S}$} \\
\hline post - test & 3.6250 & 0.55972 & & \multirow{5}{|c|}{ s-Significant } \\
\hline
\end{tabular}

Section IV: Association between the pre-test knowledge score and selected demographic variables.

In order to find out the association between the pre-test knowledge scores and the selected demographic variables, Fisher's exact test was used. The significance level selected for testing the hypothesis was 0.05

$\mathbf{H}_{2}$ : there will be significant association between the pre-test knowledge scores and the selected demographic variables. 
Table 6 : Association between pretest knowledge scores and demographic variables.

$\mathrm{n}=80$

\begin{tabular}{|c|c|c|c|c|}
\hline$\Delta$ & Poor & Average & Good & “p"value \\
\hline \\
\hline । 16 & 27 & 5 & 0 & 0.64 \\
\hline 17 & 27 & 15 & 1 & $p>0.05$ \\
\hline 18 & 2 & 3 & 0 & NS \\
\hline \multicolumn{5}{|l|}{ Group } \\
\hline I Arts & 26 & 3 & 1 & .001 \\
\hline I Science & 12 & 18 & 0 & $p<0.05$ \\
\hline I Commerce & 18 & 2 & 0 & $\mathrm{~S}$ \\
\hline \multicolumn{5}{|l|}{ Religion } \\
\hline I Hindu & 28 & 14 & 0 & .334 \\
\hline I Muslim & 11 & 5 & 1 & $p>0.05$ \\
\hline | Christian & 17 & 4 & 0 & NS \\
\hline \multicolumn{5}{|l|}{$\begin{array}{l}\text { Education of the parents } \\
\text { Father: }\end{array}$} \\
\hline I no formal education & 1 & 0 & 0 & \\
\hline I primary & 24 & 8 & 0 & .325 \\
\hline I secondary & 20 & 11 & 0 & $p>0.05$ \\
\hline I pre university & 8 & 2 & 0 & NS \\
\hline $\begin{array}{l}\text { graduation } \\
\text { and above }\end{array}$ & 3 & 2 & 1 & \\
\hline \multicolumn{5}{|l|}{ Mother: } \\
\hline I no formal education & 1 & 1 & 0 & \\
\hline I primary & 10 & 8 & 0 & .427 \\
\hline I secondary & 29 & 8 & 1 & $p>0.05$ \\
\hline I pre university & 9 & 5 & 0 & NS \\
\hline $\begin{array}{l}\text { I graduation } \\
\text { and above }\end{array}$ & 7 & 1 & 0 & \\
\hline \multicolumn{5}{|l|}{ Occupation of the parents: } \\
\hline \multicolumn{5}{|l|}{ Father: } \\
\hline | Daily wages & 25 & 10 & 0 & 0.1 \\
\hline I Employed & 25 & 4 & 0 & $p>0.05$ \\
\hline I Self employed & 6 & 8 & 1 & NS \\
\hline I Unemployed & 0 & 1 & 0 & \\
\hline \multicolumn{5}{|l|}{ Mother: } \\
\hline | Daily wages & 6 & 1 & 0 & .608 \\
\hline I Employed & 12 & 6 & 0 & $p>0.05$ \\
\hline I Self employed & 0 & 1 & 0 & NS \\
\hline | Unemployed & 38 & 15 & 1 & \\
\hline \multicolumn{5}{|l|}{ Income } \\
\hline $1<3000$ & 6 & 1 & 0 & \\
\hline I 3000-5000 & 19 & 8 & 0 & .242 \\
\hline I 5000-8000 & 15 & 7 & 0 & $p>0.05$ \\
\hline $18000-10000$ & 13 & 3 & 0 & NS \\
\hline | $>10000$ & 3 & 4 & 1 & \\
\hline \multicolumn{5}{|l|}{ Type of family: } \\
\hline I Nuclear & 4 & 18 & 0 & .125 \\
\hline I Joint & 10 & 4 & 0 & $p>0.05$ \\
\hline I extended & 2 & 1 & 1 & NS \\
\hline
\end{tabular}

NS-Not significant

\section{Discussion :}

The present study result revealed that there was significant difference between the mean pre-test and post-test knowledge scores. The pre-test mean percentage (4.37\%) scores regarding PCOS were found to be less than post-test mean percentage (12.08\%)) scores. 't'value computed between pre-test and post-test knowledge scores $\left(\mathrm{t}_{79} 2.0\right.$ $\mathrm{p} \varangle 0.05$ ) was statistically significant. Hence it was proved that the STP was effective in enhancing knowledge of adolescent girls.

The effectiveness of structured teaching programme was supported by the study which was conducted by Mamatha regarding effectiveness of planned teaching programme on Assisted reproductive technology (ART) among GNM students in a selected college at Mangalore. The study revealed that the mean Post test score was $\left(X_{2}=30.50\right)$ and mean Pre test score ( $\left.X_{1}=15.25\right)$ and the difference was significant $\left(t_{49}=1.673, P<0.01\right)$ This indicated the effectiveness of PTP in enhancing knowledge on ART.

\section{Recommendations:}

1. A similar study can be replicated with a control group

2. A similar study can be conducted to the group of adult women.

3. The study can be replicated on a larger sample for generalizing the findings.

4. A comparative study can be conducted to find out the effectiveness of structured teaching programme and SIM on the same topic.

\section{Conclusion :}

PCOS is a condition which can lead to severe health related problems and affects the reproductive youth of the country if not treated properly. Teaching adolescent girls on PCOS helps them to gain knowledge, hence helps to early detect and prevent the PCOS. The present study assessed the knowledge of adolescent girls regarding polycystic ovarian syndrome before and after the structured teaching programme. The study results revealed that adolescents have lack in knowledge about PCOS\& the knowledge level increased after the structured teaching programme. So the study concluded that structured teaching programme is effective in improving the knowledge of adolescent girls. 


\section{Reference:}

1. Wilson hockenberry, Nursing care of infants and children, $8^{\text {th }}$ edition, elsevier publishers 2007.

2. NZESYLVA'S, The problem of adolescence. August 25, 2008. Available from.http://nzesylva.wordpress.com/2008/08/25/the-problem-ofadolescence/

3. Teenagegirls, Availablefrom : URL:http://www.mehndiratta.net/ teenage_yrh02.Htm

4. Roberts Feldman. "Understanding PCOD". 6th edition. New Delhi. Grew hill publishers. 2004.

5. Dutta. DC, Text book of gynecology including contraception, 4th edition, Calcutta: new central bookagency (p) Ltd; 2006.

6. Healthwise webmed, May 11, 2010. Available from URL;http:// women.webmd.com/tc/polycystic-ovary-syndrome-pcos-topicoverview

7. Centre for young women' health. Polycystic ovary syndrome (pcos): A guide for teens. Available from: URL:http://.www.youngwomen shealth.org/index.html

8. Mareena Thomas, Effectiveness of planned teaching programme (PTP) on polycystic ovarian syndrome (pcos) for adolescent girls in a selected pre-university college at M angalore.2010. 